\title{
An Evaluation of Short-Term Forecasts of Coffee and Cocoa
}

\author{
J. Kimball Dietrich and Alfredo D. Gutierrez*
}

\begin{abstract}
Predictive performance of short-term forecasts of production is evaluated using a technique which minimizes the average squared difference between actual and forecast values. Forecasting errors are decomposed into two components reflecting the forecast system and a residual component. Many forecasts resulted in underestimation and contained large but unsystematic errors.
\end{abstract}

$\mathrm{E}$ XPoRTs of coffee and cocoa are an important source of foreign exchange to many Latin American and African nations. These tree crops are also of vital importance to the economic well-being of numerous peasant smallholders. Accordingly, there has been great concern with the export-earning prospects of various producing nations. Agencies and organizations such as the United States Foreign Agriculture Service (FAS) and the United Nations Food and Agricultural Organization (FAO) publish short-term forecasts of production in the growing regions $[1,3,11,12]$. Presumably these forecasts contribute to the policy decisions of private importers, marketing boards, and producing nations' governments. $\mathrm{U}_{\mathrm{p}}$ to the present, however, few systematic evaluations of these forecasts have been conducted. Their predictive performance is therefore comparatively unknown.

\section{Available Forecasts}

For coffee, it appears that the most easily available and probably the most widely circulated annual forecasts are those made by the FAS [12]. These official U. S. Government estimates are used often in the coffee trade and probably have considerable influence among groups that may not have access to some of the sources consulted by the FAS in preparing its estimates. In addition, the International Coffee Organization (ICO) makes short-run forecasts that are not publicly available, and George $\mathrm{G}$. Paton and Co. of New York has published

* We would like to thank Elliot J. Berg, Richard C. Porter, and Robert M. Stern, members of the Research Seminar in International Economics, and an anonymous referee for their valuable comments on an earlier version of this paper. Financial assistance was provided by the Center for Research on Economic Development, University of Michigan, and by National Science Foundation grant GS-3073 to support research in international cconomics at the University of Michigan.

J. Kimball Dietrich and Alfredo D. Gutierrez are graduate students in economics at the University of Michigan. short-run forecasts since the mid-1960's.

The FAS prepares four annual estimates of total production and exportable production (estimated total production minus estimated consumption in producing countries) for the coming coffee year, which extends officially from October 1 to September 30. Harvesting and exporting seasons, however, vary widely from country to country. The first estimate, labeled E1 by the FAS, is made the preceding June, the second, E2, in September, the third, $\mathrm{E} 3$, in December, and the fourth, E4, in March-six months into the coffee marketing year. ${ }^{1}$

Estimates are prepared on the basis of information supplied by official government statistics of the producing nations, national coffee agencies and marketing groups, as well as field reports from U. S. agricultural attachés and Foreign Service officers who conduct surveys in the producing areas with private producers, exporters, and other informal contacts. Each new estimate entails corrections of the initial figures as more accurate reports come from the field, marketing of the new crop proceeds, and new developments arise. The fourth estimate is not considered final since revisions continue for months afterward until a final published figure is determined. These figures are the main source of most of the production data used by the Pan-American Coffee Bureau in its publications [9]. FAS does not appear to generate or use these estimates with any specific purpose other than to disseminate information to those interested in current development of coffee production.

For cocoa, the published forecasts referred to were those of (1) the FAS $[11,14]$; (2) the Cocoa Study Group, Statistics Subcommittee, of the FAO [3]; and (3) Gill and Duffus, Ltd., of London [5].2

1 The estimates are published in [12] each July, October, January, and April.

The FAS forecasts are published regularly in [14], with projections in the February, October, and December issues 
Each of these agencies uses a similar survey technique of forecasting, and evidently some overlap exists in their sources of information. Each relies on sources of information within the producing country: government officials, agents of large commercial users of cocoa, and semiofficial interested groups (e.g., marketing boards). In addition, FAS uses the reports of U. S. foreign agricultural attachés for producing regions, who in turn probably rely on the types of sources mentioned earlier. Factors such as extent of spraying against pests, weather, producer prices, disease control, etc., and their effects on production prospects are incorporated in the forecasts in a judgmental manner.

Contrasting to the foregoing rather informal forecasting techniques is the cocoa production forecast prepared and submitted to the FAO by the Ministry of Agriculture, Rural Statistical Service, of the Ivory Coast. In a procedure apparently unique to the Ivory Coast, forecasts are based on a sample of approximately 400 standardized producing units throughout the country and utilize a simple pod count (with pods divided into two size classes) as a basis for production estimates in the sample units. These estimates are inflated to achieve a national production forecast $[2,4]$.

No regular review of these various forecasts is undertaken to determine their degree of reliability. Moreover, little communication seems to exist between forecasting agencies and users of the forecasts.

\section{Forecast Evaluation}

Ideally, the criterion of forecasting performance can be defined in terms of the loss function of the user of the forecasts. Moreover, from a technical standpoint, it would be desirable to detail the sources of the deviations from realized values as can be done with long-run projections which employ structural models. However, these alternatives are not available for the informal forecasting procedures being reviewed here. The method selected for determining absolute accuracy was devised by Mincer and Zarnowitz [8]. This method can be used to analyze forecasts not formulated by means

and in [11] in March and November. FAO forecasts appear quarter]y in [3]. Gill and Duffus, Ltd. [5], published quarterly, is the source of these limited-circulation forecasts. of an explicitly stated model that can be reproduced to test its predictive power.

Essentially, the Mincer-Zarnowitz technique takes as the goal of forecasting the minimization of the mean-square-error ( $M S E$ ), that is, the average squared difference between the actual and forecast values. The sample $M S E$ is defined as:

$$
M S E=\sum_{t=1}^{n} \frac{\left(A_{t}-E_{t}\right)^{2}}{N},
$$

where $A_{t}$ are actual values; $E_{t}$, forecast values; and $N$, the number of observations. This is a measure of dispersion around the line of perfect forecast $(L P F)$, which can be conceived as a $45^{\circ}$ line through the origin, and it is used to analyze absolute forecast accuracy. A least squares straight line must be fitted to a scatter diagram of actual realization $\left(A_{t}\right)$ and estimates $\left(E_{l}\right)$ :

$$
A_{t}=\alpha+\beta E_{t} \text {. }
$$

Ideally, the entire regression line should coincide with $L P F$. If the forecast is unbiased but the regression line does not coincide with $L P F$, it must intersect the $L P F$ at the mean of $A_{t}$. At ranges below the mean realizations are, on average, under- or over-predicted. The opposite tendency applies above the mean. The greater the divergence of the regression line from the $L P F$, the stronger this type of error. The larger the deviation of the slope of the regression line from unity, the less efficient the forecast.

The sample $M S E$ can be decomposed as follows:

$$
\begin{aligned}
M S E= & \sum_{t=1}^{n} \frac{\left(A_{t}-E_{t}\right)^{2}}{N}=(\bar{A}-\bar{E})^{2} \\
& +(1-\hat{\beta})^{2} S_{E}^{2}+\left(1-R_{A E^{2}}{ }^{2}\right) S_{A}{ }^{2},
\end{aligned}
$$

where $\bar{A}, \bar{F}$ are the sample means of actual and forecast values; $S_{A}^{2}$ and $S_{E}^{2}$ are their respective sample variances; $\hat{\beta}$ is the slope of the regression line; and $R^{2}$ is the coefficient of determination. The first component on the right may be termed the mean component $(M C)$, the second the slope component $(S C)$, and the third the residual component $(R C)$. If the forecast is unbiased, $M C=0$; if it is efficient, $S C=0$. In forecasts which are both unbiased and efficient, $M C$ and $S C$ disappear, and the $M S E$ equals the residual variance $(R C) . M C$ and $S C$ can be interpreted as that portion of error resulting from systematic tendencies of the forecast system. In dealing with limited samples of esti- 
mates and realizations, the calculated $M S E$ 's, their components, and the regression statistics are all subject to sampling variation. Thus, even if the estimates are unbiased and efficient in the population, the sample will show unequal means of estimates and realizations, a nonzero intercept in the regression of $A$ on $E$, a slope different from unity, and nonzero mean and slope components.

To determine whether the forecasts are unbiased and/or efficient, tests of statistical significance are required. The test that $E$ is both unbiased and efficient is the test of the joint null hypothesis: $\alpha=0, \beta=1$. The test of efficiency is the test of the null hypothesis: $\beta=1$.

To give some idea of overall forecast accuracy, the square root of the $M S E$ has been computed and expressed as a percent of the actual mean value. While it is tempting to use the $R^{2}$ resulting from the regressions as some measure of forecast accuracy, the $R^{2}$ is not a reliable guide since in the above analysis it merely represents errors explained by a linear adjustment of the forecast series.

The Mincer-Zarnowitz technique is not without its difficulties. First, this analysis evaluates forecasts only in terms of systematic errors. It does not establish a criterion for choosing between good and bad forecasts except in a few unambiguous cases where an unbiased, efficient forecast with a small $M S E$ can be chosen over a biased, inefficient forecast with a larger $M S E$. More likely is the case where one forecast may have a small $M S E$ but a large relative $M C$ and $S C$, while another unbiased, efficient forecast (small $M C$ and $S C$ ) has the same or larger $M S E$ representing unsystematic errors. In other words, large random errors that cannot be reduced by a linear adjustment of the forecast may result in a low correlation between forecast and actual values and yet have very small mean and slope-component errors.

A second problem is raised by the inherent quadratic loss function arising from use of the $M S E$ criterion. One result is that the analysis is symmetric with respect to type of error; that is, a downward or an upward bias or either type of inefficiency is evaluated equally. There is no reason, however, to expect that any of the user's loss functions would be symmetric. For example, from the standpoint of decision makers, planning for more world production (and lower price expectations) than is realized would not necessarily cost the same as consistently underestimating world production.

\section{Coffee Forecast Evaluations}

Four annual FAS coffee exportable production forecasts were analyzed ${ }^{3}$ for each of the five leading producing countries and for the three regional producing areas (Table 1). In general the statistical tests of the joint null hypothesis for bias and inefficiency indicated that few of the annual estimates could be rejected as being significantly different from the null hypothesis $(\alpha=0, \beta=1)$. Except in the case of Brazil, the analysis revealed a tendency to underestimate low values and overestimate large values. However, the results were not statistically significant for any of the cases. For all individual countries and regions analyzed, rejection of the joint hypotheses occurred in $\mathbf{1 6}$ percent of the cases: E2, E3, and E4 for Colombia, E1 for Angola, and E1 for the Rest of Africa. The null hypothesis $\beta=1$ was also rejected in 16 percent of the cases: E2, E3, and E4 for Colombia, E1 for Angola, and E3 for the Rest of Africa. This indicated that the main cause of poor performance in forecasting was due to inefficiency rather than bias.

For each forecast mentioned, Table 1 shows the difference between the actual and forecast means, giving the direction of bias, the square root of the MSE over the mean of the actuals, and the $M C, S C$, and $R C$ of the $M S E$. These details are all expressed in percentage form. The last column of Table 1 designates whether the test of bias and efficiency indicates rejection at the 95 percent confidence level.

On the average, the $M C$ accounted for 8.1 percent of the $M S E$, the $S C 12.8$ percent, and the $R C 79.1$ percent of the error. Although 81 percent of the estimates showed a downward bias, this bias was statistically significant in only two cases: E1 for Angola and E1 for the Rest of Africa. The square-root $M S E$ measure showed that the great majority of estimating errors decreased with each new estimate for that year, as expected. The largest forecasting errors occurred in the Ivory Coast and the smallest in Other Western Hemisphere. The FAS estimates generally were very good by the absolute accuracy standard. This is not surprising since the FAS estimates are made close enough to the harvesting season in most countries and revised often enough that crucial factors such as frosts, droughts, and rain dam-

\footnotetext{
3 The complete results of the analysis described in this and the following section are available from the authors by request.
} 
Table 1. Summary of analysis of mean-square error of FAS short-term forecasts for coffee

\begin{tabular}{|c|c|c|c|c|c|c|c|}
\hline \multirow{2}{*}{ Producing Countries and Areas } & \multirow{2}{*}{$\begin{array}{l}\text { Fore- } \\
\text { casts }\end{array}$} & \multicolumn{3}{|c|}{ Decomposition of Error } & \multirow{2}{*}{$\begin{array}{c}\text { Square } \\
\text { Root } \\
M S E \text { as } \\
\text { Percent of } \\
\text { Actual } \\
\text { Mean }\end{array}$} & \multirow{2}{*}{$\begin{array}{c}\text { Forecast } \\
\text { Mean } \\
\text { Bias }\end{array}$} & \multirow{2}{*}{$\begin{array}{l}\text { Rejected } \\
\text { as } \\
\text { Biased } \\
\text { and } \\
\text { Inefficient }\end{array}$} \\
\hline & & $M C$ & $S C$ & $R C$ & & & \\
\hline Brazil & $\begin{array}{l}\text { E1 } \\
\text { E2 } \\
\text { E3 } \\
\text { E4 }\end{array}$ & $\begin{array}{c}4.04 \% \\
.09 \\
10.55 \\
10.75\end{array}$ & $\begin{array}{c}.33 \% \\
6.40 \\
12.35 \\
7.62\end{array}$ & $\begin{array}{l}95.63 \% \\
93.51 \\
77.10 \\
81.63\end{array}$ & $\begin{array}{c}22.54 \% \\
16.72 \\
12.44 \\
5.86\end{array}$ & $\begin{aligned} & 4.53 \% \\
&- .49 \\
&- 4.04 \\
&-1.92\end{aligned}$ & $\begin{array}{l}\text { No } \\
\text { No } \\
\text { No } \\
\text { No }\end{array}$ \\
\hline Colombia & $\begin{array}{l}\text { E1 } \\
\text { E2 } \\
\text { E3 } \\
\text { E4 }\end{array}$ & $\begin{array}{r}4.41 \\
.32 \\
2.24 \\
9.43\end{array}$ & $\begin{array}{r}5.72 \\
46.93 \\
58.04 \\
40.17\end{array}$ & $\begin{array}{l}89.87 \\
52.75 \\
39.73 \\
50.40\end{array}$ & $\begin{array}{l}9.93 \\
6.50 \\
7.42 \\
6.67\end{array}$ & $\begin{array}{r}2.08 \\
-\quad .37 \\
-1.11 \\
-2.05\end{array}$ & $\begin{array}{l}\text { No } \\
\text { Yes } \\
\text { Yes } \\
\text { Yes }\end{array}$ \\
\hline Ivory Coast & $\begin{array}{l}\text { E1 } \\
\text { E2 } \\
\text { E3 } \\
\text { E4 }\end{array}$ & $\begin{array}{r}.13 \\
1.54 \\
1.50 \\
.20\end{array}$ & $\begin{array}{r}.51 \\
.91 \\
1.63 \\
2.26\end{array}$ & $\begin{array}{l}99.36 \\
97.55 \\
96.87 \\
97.54\end{array}$ & $\begin{array}{l}23.83 \\
20.94 \\
20.40 \\
15.20\end{array}$ & $\begin{array}{r}-.85 \\
2.60 \\
2.50 \\
-\quad .68\end{array}$ & $\begin{array}{l}\text { No } \\
\text { No } \\
\text { No } \\
\text { No }\end{array}$ \\
\hline Angola & $\begin{array}{l}\text { E1 } \\
\text { E2 } \\
\text { E3 } \\
\text { E4 }\end{array}$ & $\begin{array}{r}18.49 \\
5.63 \\
4.04 \\
.11\end{array}$ & $\begin{array}{l}14.73 \\
24.74 \\
20.41 \\
19.73\end{array}$ & $\begin{array}{l}66.78 \\
69.62 \\
75.56 \\
80.16\end{array}$ & $\begin{array}{r}19.67 \\
13.61 \\
9.34 \\
5.96\end{array}$ & $\begin{array}{l}-8.46 \\
-3.23 \\
-1.88 \\
-\quad .20\end{array}$ & $\begin{array}{l}\text { Yes } \\
\text { No } \\
\text { No } \\
\text { No }\end{array}$ \\
\hline Uganda & $\begin{array}{l}\text { E1 } \\
\text { E2 } \\
\text { E3 } \\
\text { E4 }\end{array}$ & $\begin{array}{r}11.49 \\
7.15 \\
12.51 \\
7.46\end{array}$ & $\begin{array}{r}3.87 \\
5.83 \\
8.56 \\
12.69\end{array}$ & $\begin{array}{l}84.64 \\
87.02 \\
78.93 \\
79.85\end{array}$ & $\begin{array}{l}19.28 \\
15.63 \\
14.56 \\
13.33\end{array}$ & $\begin{array}{l}-6.54 \\
-4.18 \\
-5.15 \\
-3.64\end{array}$ & $\begin{array}{l}\text { No } \\
\text { No } \\
\text { No } \\
\text { No }\end{array}$ \\
\hline Other Western Hemisphere & $\begin{array}{l}\text { E1 } \\
\text { E2 } \\
\text { E3 } \\
\text { E4 }\end{array}$ & $\begin{array}{l}.64 \\
7.43 \\
4.16 \\
2.14\end{array}$ & $\begin{array}{r}12.61 \\
12.34 \\
10.29 \\
2.71\end{array}$ & $\begin{array}{l}86.76 \\
80.24 \\
85.55 \\
95.15\end{array}$ & $\begin{array}{l}6.12 \\
5.99 \\
5.68 \\
4.30\end{array}$ & $\begin{array}{r}-.49 \\
1.63 \\
1.16 \\
-\quad .63\end{array}$ & $\begin{array}{l}\text { No } \\
\text { No } \\
\text { No } \\
\text { No }\end{array}$ \\
\hline Rest of Africa & $\begin{array}{l}\mathrm{E} 1 \\
\mathrm{E} 2 \\
\mathrm{E} 3 \\
\mathrm{E} 4\end{array}$ & $\begin{array}{r}50.50 \\
24.37 \\
6.56 \\
26.52\end{array}$ & $\begin{array}{r}3.10 \\
1.89 \\
25.79 \\
.90\end{array}$ & $\begin{array}{l}46.40 \\
73.74 \\
67.64 \\
72.58\end{array}$ & $\begin{array}{l}8.72 \\
5.94 \\
6.34 \\
5.05\end{array}$ & $\begin{array}{l}-6.20 \\
-2.93 \\
-1.62 \\
-2.60\end{array}$ & $\begin{array}{l}\text { Yes } \\
\text { No } \\
\text { No } \\
\text { No }\end{array}$ \\
\hline Asia and Oceania & $\begin{array}{l}\text { E1 } \\
\text { E2 } \\
\text { E3 } \\
\text { E4 }\end{array}$ & $\begin{array}{r}15.15 \\
4.57 \\
.96 \\
3.95\end{array}$ & $\begin{array}{r}4.64 \\
10.39 \\
14.59 \\
15.58\end{array}$ & $\begin{array}{l}80.20 \\
85.04 \\
84.44 \\
80.47\end{array}$ & $\begin{array}{l}22.23 \\
15.26 \\
15.52 \\
14.63\end{array}$ & $\begin{array}{l}-8.65 \\
-3.26 \\
-1.52 \\
-2.91\end{array}$ & $\begin{array}{l}\text { No } \\
\text { No } \\
\text { No } \\
\text { No }\end{array}$ \\
\hline All areas except Brazil & $\begin{array}{l}\mathrm{E} 1 \\
\mathrm{E} 2 \\
\mathrm{E} 3 \\
\mathrm{E} 4\end{array}$ & $\begin{array}{r}16.46 \\
4.22 \\
3.91 \\
12.78\end{array}$ & $\begin{array}{r}2.32 \\
17.61 \\
18.34 \\
15.70\end{array}$ & $\begin{array}{l}81.22 \\
78.17 \\
77.75 \\
71.52\end{array}$ & $\begin{array}{l}5.92 \\
4.38 \\
4.91 \\
4.88\end{array}$ & $\begin{array}{l}-2.40 \\
-\quad .90 \\
-.97 \\
-1.75\end{array}$ & $\begin{array}{l}\text { No } \\
\text { No } \\
\text { No } \\
\text { No }\end{array}$ \\
\hline All producing areas & $\begin{array}{l}\text { E1 } \\
\text { E2 } \\
\text { E3 } \\
\text { E4 }\end{array}$ & $\begin{array}{r}.08 \\
.95 \\
9.74 \\
15.55\end{array}$ & $\begin{array}{l}.36 \\
2.70 \\
5.98 \\
5.88\end{array}$ & $\begin{array}{l}99.56 \\
96.35 \\
84.28 \\
78.56\end{array}$ & $\begin{array}{r}10.57 \\
7.71 \\
6.62 \\
4.58\end{array}$ & $\begin{array}{r}.30 \\
-.75 \\
-2.07 \\
-1.81\end{array}$ & $\begin{array}{l}\text { No } \\
\text { No } \\
\text { No } \\
\text { No }\end{array}$ \\
\hline
\end{tabular}

age can be taken into consideration.

The general tendency for underestimation of actual production could be attributed to a natural reaction of producers to make low estimates of yearly crops with price considerations in mind. Another reason might be that the trend toward more peasant smallholders and smaller producing units [7] has made it more difficult to keep track of production. Finally, price ex- pectations induced by the forecasts may provoke a production response. ${ }^{4}$

The tendency in Brazil to overestimate low values and underestimate large ones can be attributed to the great variability of production in that region. Rourke [10], using essentially

4 For an analysis of this issue in the context of the statistical reporting of U. S. farm commodities, see Hayami and Peterson [6]. 
the same data, found that 86.13 percent of the total variability in year-to-year changes in all producing areas' production was contributed directly by Brazil. The poor forecasting performance for Colombia was also noted by Rourke. He attributed this result to the diversity of production conditions in that country, with large differences in elevation and climatic conditions making coffee yields difficult to predict. A correction factor accounting for these conditions does not seem feasible due to the random nature of the forecast errors.

Two areas where the downward bias was statistically significant can be traced to large underestimates in those regions for particular years. For Angola the first annual estimates for the coffee years 1960-61 and 1961-62 showed underestimates of almost 1 million bags each year. This is large considering that Angolan production was around 2.75 million bags in both years-an increase of more than a million bags over the previous years. The same is true for the Rest of Africa for the years 1958-59 and 1959-60. These years are very significant since they mark the beginning of a sharp expansion of output due to increased new plantings during the 1950's as producers reacted to the high prices that existed during the first half of the decade.

The FAS estimates performed relatively well in predicting annual exportable production. However, the analysis was only an initial step in the evaluation of short-term forecasts. Several important questions remain unanswered. More information is needed regarding the precise methods used by foreign agricultural attachés and the FAS in generating their data, to determine how the consistent pattern of underestimation arises. Knowledge of the source of this error should lead to better forecasts by introducing a correction factor into the country estimates. If the reason for this underestimation is the increasing number and size of small- and medium-size producing units, it should be possible to find a correlation between changes in the number and size of growing units and the magnitude of the underestimation.

Another important question left unanswered is the poor performance of forecasts in the case of Colombia. As noted above, the various climatic and elevation conditions prevailing there may make forecasting difficult. But this explanation has not been substantiated to any extent. In addition, it would be useful to test the ability of the FAS forecasts to predict annual production changes rather than total production figures. Finally, a comparative study is needed using the FAS, ICO, and individual producing nations' forecasts to test for relative accuracy and to determine whether the same estimation patterns occur within the different sources.

\section{Cocoa Forecast Evaluations}

In analyzing cocoa forecasts, the performance of three agencies could be compared. At least two forecasts were made for 36 of the 37 cocoaproducing regions for which series were available. On the basis of simple comparisons of the mean error, no general preference for either the FAS, Gill and Duffus, or FAO forecasts could be determined. FAS had the smallest percentage error in 17 of the cases, followed by Gill and Duffus and FAO with 10 and 9, respectively. In only seven cases could an absolute preference for a forecast be decided on the basis of smaller percentage errors together with smaller percentage systematic error components. These were distributed three cases each for FAS and FAO, and one for Gill and Duffus.

Several patterns emerged: production forecasts for African countries tended to have a downward bias; yet the proportion of forecasts having errors 20 percent or larger was smaller there than elsewhere. Forecasts for the rest of the world tended to have an upward bias, and more than half the forecasts had errors 20 percent or larger. About two-thirds of all forecasts had slope component errors of 10 percent or more.

The number of cases for each continental group that could be rejected as biased and inefficient on the basis of statistical tests varied between producing regions. For all South American countries, less than half of the forecasts failed this statistical test; for the rest of the world a much higher proportion (roughly two-thirds) could be considered biased and inefficient. Since the South American forecasts were characterized by a percent square root $M S E$ as high or higher than the rest of the world's forecasts, South American forecasts are clear examples of cases where large but unsystematic errors pervade a forecasting effort. They are no better or worse than other forecasts for this reason alone, however. This exemplifies the unsatisfying ambiguity that remains after performing this type of analysis. 
Table 2. Summary of analysis of mean-square error of short-term forecasts for cocoa

\begin{tabular}{|c|c|c|c|c|c|c|c|}
\hline \multirow{2}{*}{ Region } & \multirow{2}{*}{$\begin{array}{c}\text { Forecast } \\
\text { Agency }\end{array}$} & \multicolumn{3}{|c|}{ Decomposition of Error } & \multirow{2}{*}{$\begin{array}{c}\text { Square Root } \\
M S E \text { as } \\
\text { Percent of } \\
\text { Actual } \\
\text { Mean }\end{array}$} & \multirow{2}{*}{$\begin{array}{l}\text { Forecast } \\
\text { Mean Bias }\end{array}$} & \multirow{2}{*}{$\begin{array}{c}\text { Rejected } \\
\text { as Biased } \\
\text { and Inef- } \\
\text { ficient }\end{array}$} \\
\hline & & $M C$ & $S C$ & $R C$ & & & \\
\hline Brazil & $\begin{array}{l}\text { FAS } \\
\text { G\&D* } \\
\text { FAO }\end{array}$ & $\begin{array}{l}.27 \% \\
.76 \\
.08\end{array}$ & $\begin{array}{l}19.92 \% \\
13.67 \\
10.33\end{array}$ & $\begin{array}{l}79.81 \% \\
85.56 \\
89.59\end{array}$ & $\begin{array}{l}19.75 \% \\
21.08 \\
18.88\end{array}$ & $\begin{array}{r}1.03 \\
-1.84 \\
-\quad .54\end{array}$ & $\begin{array}{l}\text { No } \\
\text { No } \\
\text { No }\end{array}$ \\
\hline Ecuador & $\begin{array}{l}\text { FAS } \\
\text { G\&D } \\
\text { FAO }\end{array}$ & $\begin{array}{l}13.93 \\
20.15 \\
12.05\end{array}$ & $\begin{array}{r}.39 \\
2.95 \\
7.34\end{array}$ & $\begin{array}{l}85.68 \\
76.90 \\
80.61\end{array}$ & $\begin{array}{l}21.37 \\
20.88 \\
21.54\end{array}$ & $\begin{array}{l}-7.98 \\
-9.37 \\
-7.48\end{array}$ & $\begin{array}{l}\text { No } \\
\text { No } \\
\text { No }\end{array}$ \\
\hline Venezuela & $\begin{array}{l}\text { FAS } \\
\text { G\&D } \\
\text { FAO }\end{array}$ & $\begin{array}{l}.43 \\
4.31 \\
4.11\end{array}$ & $\begin{array}{l}9.66 \\
7.54 \\
5.81\end{array}$ & $\begin{array}{l}89.91 \\
88.15 \\
90.09\end{array}$ & $\begin{array}{l}20.07 \\
17.94 \\
19.53\end{array}$ & $\begin{array}{l}-1.32 \\
-3.72 \\
-3.96\end{array}$ & $\begin{array}{l}\text { No } \\
\text { No } \\
\text { No }\end{array}$ \\
\hline South America & $\begin{array}{l}\text { FAS } \\
\text { FAO }\end{array}$ & $\begin{array}{l}.00 \\
.37\end{array}$ & $\begin{array}{r}.96 \\
1.37\end{array}$ & $\begin{array}{l}99.03 \\
98.25\end{array}$ & $\begin{array}{l}12.25 \\
11.45\end{array}$ & $=.06$ & $\begin{array}{l}\text { No } \\
\text { No }\end{array}$ \\
\hline Ghana & $\begin{array}{l}\text { FAS } \\
\text { G\&D } \\
\text { FAO }\end{array}$ & $\begin{array}{r}2.01 \\
8.64 \\
15.29\end{array}$ & $\begin{array}{l}12.96 \\
44.72 \\
67.59\end{array}$ & $\begin{array}{l}85.03 \\
46.64 \\
17.11\end{array}$ & $\begin{array}{l}18.19 \\
14.03 \\
23.73\end{array}$ & $\begin{array}{l}-2.58 \\
-4.12 \\
-9.28\end{array}$ & $\begin{array}{l}\text { No } \\
\text { Yes } \\
\text { Yes }\end{array}$ \\
\hline Nigeria & $\begin{array}{l}\text { FAS } \\
\text { G\&D } \\
\text { FAO }\end{array}$ & $\begin{array}{r}.47 \\
8.79 \\
23.14\end{array}$ & $\begin{array}{r}10.83 \\
35.39 \\
8.71\end{array}$ & $\begin{array}{l}88.70 \\
55.82 \\
68.16\end{array}$ & $\begin{array}{l}22.77 \\
16.20 \\
18.88\end{array}$ & $\begin{array}{l}-1.57 \\
-4.80 \\
-9.08\end{array}$ & $\begin{array}{l}\text { No } \\
\text { Yes } \\
\text { No }\end{array}$ \\
\hline Cameroons & $\begin{array}{l}\text { FAS } \\
\text { G\&D } \\
\text { FAO }\end{array}$ & $\begin{array}{r}2.76 \\
.18 \\
6.28\end{array}$ & $\begin{array}{r}.01 \\
9.40 \\
72.81\end{array}$ & $\begin{array}{l}97.24 \\
90.42 \\
20.91\end{array}$ & $\begin{array}{r}9.44 \\
7.37 \\
23.00\end{array}$ & $\begin{array}{r}-1.57 \\
.31 \\
-5.76\end{array}$ & $\begin{array}{l}\text { No } \\
\text { No } \\
\text { Yes }\end{array}$ \\
\hline Ivory Coast & $\begin{array}{l}\text { FAS } \\
\text { G\&D } \\
\text { FAO }\end{array}$ & $\begin{array}{l}13.78 \\
42.37 \\
37.87\end{array}$ & $\begin{array}{r}2.87 \\
.57 \\
.08\end{array}$ & $\begin{array}{l}83.93 \\
57.05 \\
62.05\end{array}$ & $\begin{array}{l}19.26 \\
13.95 \\
16.10\end{array}$ & $\begin{array}{l}-7.15 \\
-9.08 \\
-9.91\end{array}$ & $\begin{array}{l}\text { No } \\
\text { Yes } \\
\text { No }\end{array}$ \\
\hline Africa & $\begin{array}{l}\text { FAS } \\
\text { FAO }\end{array}$ & $\begin{array}{r}3.25 \\
25.48\end{array}$ & $\begin{array}{l}8.00 \\
7.44\end{array}$ & $\begin{array}{l}88.75 \\
67.09\end{array}$ & $\begin{array}{l}15.26 \\
12.17\end{array}$ & $\begin{array}{l}-2.75 \\
-6.14\end{array}$ & $\begin{array}{l}\text { No } \\
\text { No }\end{array}$ \\
\hline $\begin{array}{l}\text { Asia and } \\
\text { Oceania }\end{array}$ & $\begin{array}{l}\text { FAS } \\
\text { FAO }\end{array}$ & $\begin{array}{r}4.43 \\
33.55\end{array}$ & $\begin{array}{l}35.82 \\
49.05\end{array}$ & $\begin{array}{l}59.75 \\
17.39\end{array}$ & $\begin{array}{l}13.64 \\
17.07\end{array}$ & $\begin{array}{l}2.87 \\
9.89\end{array}$ & $\begin{array}{l}\text { Yes } \\
\text { Yes }\end{array}$ \\
\hline $\begin{array}{l}\text { All producing } \\
\text { areas }\end{array}$ & $\begin{array}{l}\text { FAS } \\
\text { G\&D } \\
\text { FAO }\end{array}$ & $\begin{array}{r}2.36 \\
11.86 \\
21.11\end{array}$ & $\begin{array}{r}7.43 \\
41.28 \\
10.39\end{array}$ & $\begin{array}{l}90.21 \\
46.86 \\
68.49\end{array}$ & $\begin{array}{r}10.71 \\
7.98 \\
8.48\end{array}$ & $\begin{array}{l}-1.65 \\
-2.75 \\
-3.90\end{array}$ & $\begin{array}{l}\text { No } \\
\text { Yes } \\
\text { No }\end{array}$ \\
\hline
\end{tabular}

* Gill \& Duffus

Some of the more important series, measured in terms of their share of world production, were chosen for presentation here. The main results are shown in Table 2 , which has the same format as Table 1 . The analysis focused on Brazil, Ecuador, and Venezuela, the three largest South American producers, together accounting for 92 percent of that continent's production over the period; Ghana and Nigeria, the two largest African producers, and the Cameroons and the Ivory Coast, two fastgrowing African producers, all four of which accounted for 92 percent of African production over the period; and the totals for South America, Africa, Oceania, and Asia, accounting for 85 percent of total production; and total world production. The results from these important regions are typical of the complete analysis of all countries in the sample.

Many of these series analyzed in Table 2 were inefficient, and the tendency was for forecast errors to be overestimates at large forecast magnitudes. However, a smaller proportion of these large-producer forecasts (under a third) had statistically significant systematic errors as compared to the complete set (where over half could be rejected as biased and inefficient).

On the basis of the results, the analysis of short-term production forecasts of cocoa can be generalized as follows:

(1) South American forecasts did not err systematically, but the general level of errors 
was the same or higher than that for countries elsewhere.

(2) African forecasts tended to be biased downward, and where total errors (as measured by the root $M S E$ as a percent of actual means) were of the same magnitude or a little less than elsewhere, these errors could in more cases be shown to be systematic.

(3) Inefficiency was of the type tending to associate overestimates with large actual figures. This was true of all three forecasting agency series.

(4) On the basis of statistical tests, the FAS showed less of a tendency to make systematic errors. However, it shared the general characteristics of the other forecasts with respect to downward bias in African production estimates.

\section{Conclusion}

On the basis of analysis it cannot be concluded that present forecasting efforts for coffee and cocoa are good or bad, or that, in the case of cocoa, one agency's forecasts are to be preferred over another's. This is an unsatisfying result, which stems from some of the limitations of the Mincer-Zarnowitz procedure noted earlier. However, it was shown that many series contained bias or inefficiency of a particular type or were plagued by large but unsystematic errors. An unresolved issue is how important these various considerations are with respect to the users of the forecasts. Unfortunately this cannot be determined in the absence of adequate knowledge of the cost of forecast errors to the users.

Recent work, especially by Hayami and Peterson [6, p. 128], indicates that investment in the improvement of official forecasts of domestically produced U. S. commodities may have a high social rate of return. However, in the case of coffee and cocoa forecasts, it is not clear that reduction in forecast variance can be directly related to the costs of expanding the current forecasting effort. The reason is that this effort rests on the cooperation of dispersed sources of information that are not always involved in the production of the commodities. On the other hand, it is likely that improvements in data collection involving, for example, tree plantings, acreage, spraying, etc., will lead to the development of structured models for short-run forecasting of coffee and cocoa. Perfection of such models together with a better understanding of the costs of forecast errors to decision makers would make forecast evaluation of the kind attempted here a more straightforward and unambiguous exercise.

\section{References}

[1] Food and Agricultural Organization of the United Nations, Monthly Bulletin of Agriculhural Economics and Statistics, Rome, various issues, 1958-1970.

[2] __ "Report on Forecasting Techniques for Cocoa Production in the Ivory Coast," Rome, March 6, 1967.

[3] - Cocoa Study Group, Cocoa Statistics, Rome, published quarterly, 1958-70.

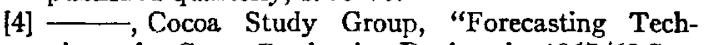
niques for Cocoa Production During the 1967/68 Season in the Ivory Coast," Rome, April 21, 1969.

[5] Gill and Duffus, Ltd., Cocoa Market Report, London, various issues, 1960-70.

[6] Hayami, Yojtro, and Willis Peterson, "Social Returns to Public Information Services: Statistical Reporting of U. S. Farm Commodities," Am. Econ. Reo. 62:119-130, March 1972.

[7] Krug, C. A., AND R. A. DePoerck, World Coffee Survey, Rome, Food and Agricultural Organization, 1968.

[8] Mincer, JaCoB, and Victor Zarnowitz, "The Eval- uation of Economics Forecasts," in ed. Jacob Mincer, Economic Forecasts and Expectations: Analyses of Forecasting Behavior and Performance, New York, National Bureau of Economic Research, 1969.

[9] Pan-American Coffee Bureau, Annual Coffee Statistics, New York, 1948-1969.

[10] ROURKE, BLAIR E., "Short Range Forecasting of Coffee Production," Food Research Institute Monograph, Stanford, Stanford University, 1970.

[11] U. S. Department of Agriculture, Foreign Agriculture Service, Foreign Agricultural Circular: Cocoa Beans, Washington, various issues, 1956-1970.

[12] —_, Foreign Agriculhural Circular: Coffee, Washington, various issues, 1963-1970.

[13] - Foreign Crops and Markets, Washington, various issues, 1946-1955.

[14] $\longrightarrow$, World Agricultural Production and Trade, Statistical Reports, Washington, various issues, 1958-70. 